\title{
Impact of geology and climate change on wetlands: Case of Lake Aguelmam Azegza (Middle Atlas, Morocco)
}

\author{
Abdelaziz Boutsougame ${ }^{1 *}$, Lahcen El Youssfi ${ }^{4}$, Hlima Aassine ${ }^{3}$, Soufiane Khuili ${ }^{3}$, Sidi Imad Cherkaoui ${ }^{1}$, Hassane \\ Ouazzani ${ }^{2}$, and Mustapha Alaoui ${ }^{3}$ \\ ${ }^{1}$ EGRN research team, LPSTS Laboraotory, Higher School of Technology of Khenifra, Sultane Moulay Slimane University, \\ Khenifra, Morocco \\ 2 Faculty of Sciences, Department of Geology, Meknes, Morocco \\ 3 Sciences and Technologies Faculty of Sultan Moulay Slimane University, Beni Mellal, Morocco \\ ${ }^{4}$ RN2D Laboratory, Kénitra National Higher School of Chemistry ENSC, Ibn Tofail University, B.P. 241, 14000, Kénitra, Morocco
}

\begin{abstract}
The AguelmamAzegza lake is located in the Middle Atlas mountain range, this region consists of carbonate rocks of Lias. It is the best-watered and richest region in Morocco in terms of wetlands, especially natural lakes, rivers and fresh springs. The lake's water supply is ensured by the inflows of water in the form of underwater sources fed by precipitation (rain and snow) following tectonics and the genesis of karstic formations by the dissolution of carbonate rocks. The declining trend in lake levels in recent years results from the decrease in precipitation which decreases during these years.
\end{abstract}

\section{Introduction}

The AguelmamAzegza lake is a natural lake located $30 \mathrm{~km}$ east of the town of Khénifra in the heart of the Middle Atlas (Ajdir Causse) at an altitude of 1546m. It belongs to the structural domain of the Middle Atlas Causse, a karstic domain affected by tectonics, formed by carbonate rocks (limestone and dolomites) of the Lias which lies on soft red clay rocks and altered basalts of the Triassic (Lepoutre and Martin, 1967).

The Middle Atlas, to which the AguelmamAzegza lake belongs, constitutes a favourable environment for the genesis of karstic formations following the dissolution of the carbonate rocks that form the major part of the Middle Atlas landscape. This dissolution is due to the intense fracturing that the mountain range has undergone the humid climate, the low temperatures and the accumulation of snow during the winter (Martin, 1981). This karstification allows, on the one hand, the penetration and storage of a very high proportion of meteoric water by infiltration (Bentayeb and Leclerc, 1977), and on the other hand, the filling of the groundwater network.

The specific objectives assigned to this work consist in the synthesis of geological and hydrological data from different sources of punctual observations, analyses and spatialized information in the years 2012/13/15/16/17/18/19/2020 to note the effect of the dissolution of the carbonate geological formations and of the climatic changes on the water levels of lake AguelmamAzegza.

\section{Location and geological context}

The delimitation of the impluvium of AguelmamAzegza was carried out by means of the maps of Karrouchan 1/50000, Al Hammam 1/50000 and with the help of prospecting field visits. The surface area of the delimited basin is 911 ha. Lake Azegza is part of the upper basin of the Oum Er Rbia, occupying a deep NW-SE elongated depression with an average depth of $26 \mathrm{~m}$ and an area of about 50 ha. It belongs to a small catchment area of about $10.62 \mathrm{~km} 2$ (Fig. 1) and is limited to the south by a sheer cliff. It is surrounded by limestone reliefs which are covered by a forest of Quercus rotundi folia (holm oak) and Cedrus atlantica (Atlas cedar). Its water supply is ensured by precipitation (rain and snow), runoff and underground water inputs (Benkaddouret al., 2008).

This lake is located in a region with a Mediterranean mountain climate, which is characterized by a humid and cold climate (Martin, 1981).

\footnotetext{
*Corresponding author:a.boutsougame@usms.ma
} 

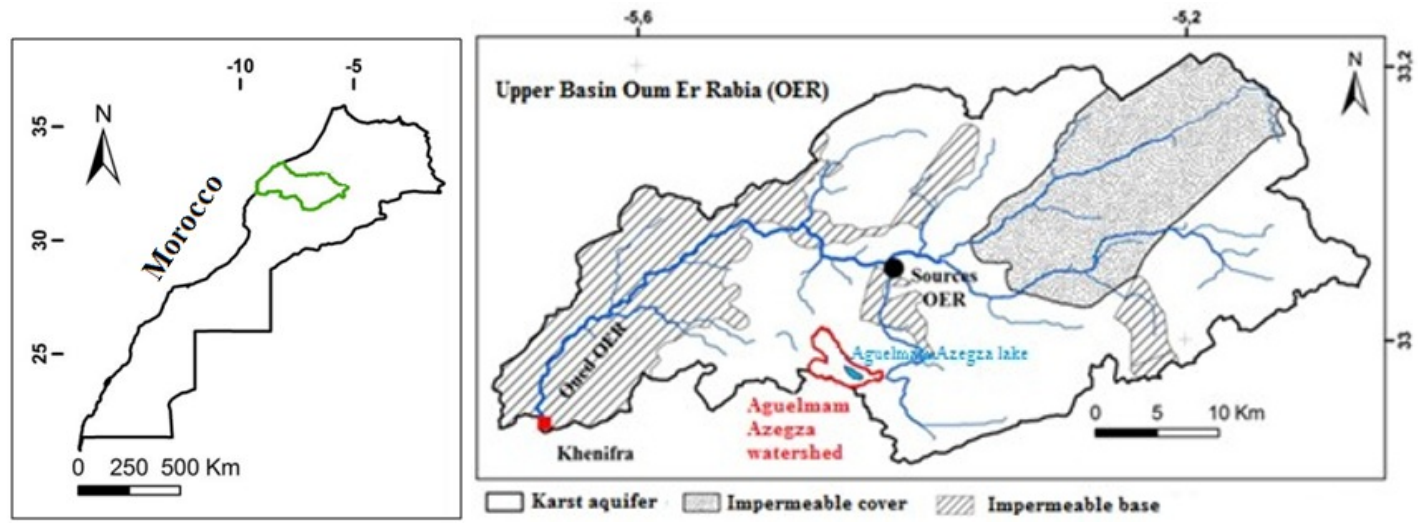

Fig. 1.Geographicallocation of the AguelmamAzegza lake and its catchment area on the hydrogeological map of the Upper Oum Er Rbia basin (Bentayeb and Leclerc, 1977).

Lake Azegza is one of the lakes of tectono-karstic origin (Hinaje and Ait Brahim, 2002). The Ajdir causse, of which the lake is a part, is located between the Aghbal and Srou limestone plateaus and constitutes the western part of the Bekrit syncline. In the western part of the Bekrit syncline, the structuring has generated submeridian faults and folds. The latter are the result of the detachment of the Liassic formations from the Triassic clay-salt. The installation of synclinal basins has favoured the karstification of the Liassic calcareous-dolomitic formations and the development of most of the poljes in this site. The whole area is part of the structural domain of the Middle Atlas causse, which offers the classic landscapes of high limestone plateaus, hence the name of causse. This is the domain of carbonate rocks: limestones and dolomites of the Lias which lie on soft red clayey-marl rocks of the Triassic (Lepoutre and Martin, 1967)(Fig.2).

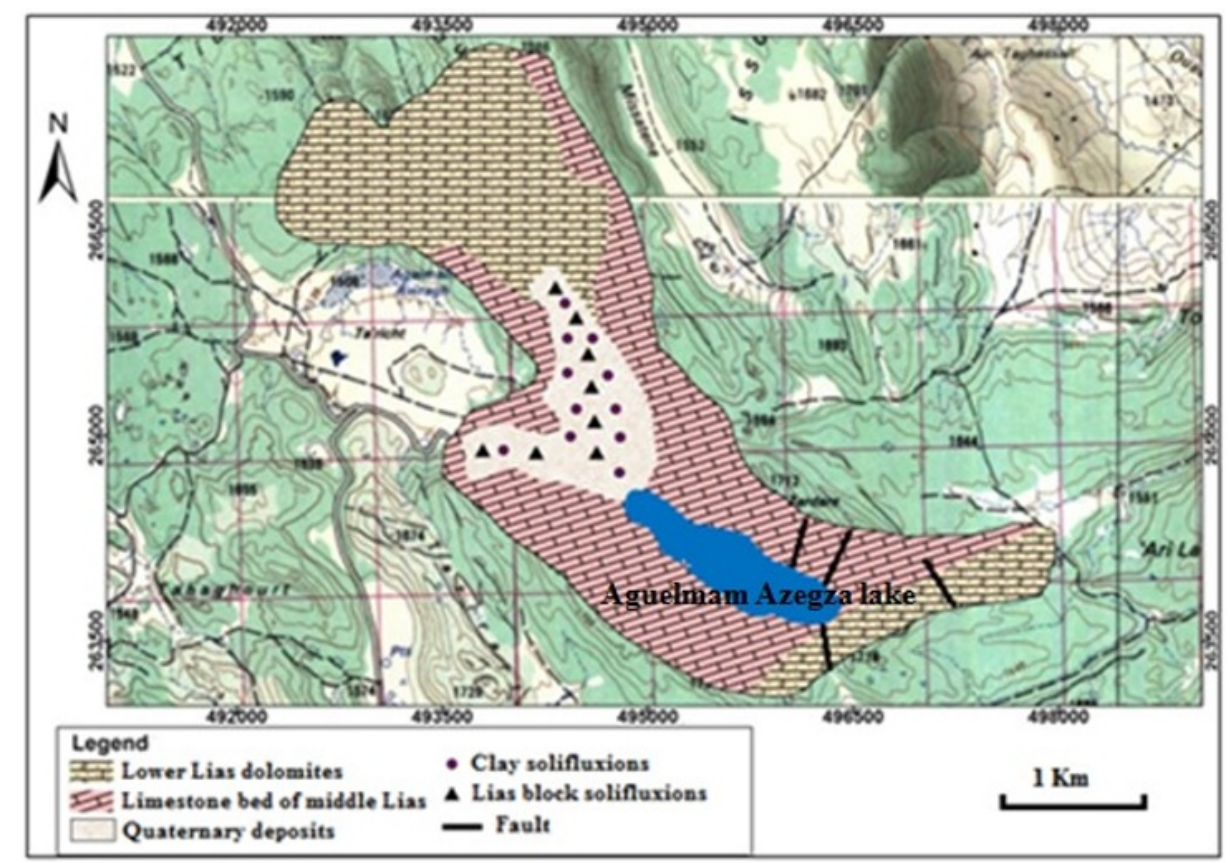

Fig. 2.Lithological map of the lower basin of AguelmamAzegza.

\section{Geological conditions}

\subsection{Tectonics}

The AguelmamAzegza lake is fed through the anomalous contact between the crushed and faulted limestone formations that lead the water to the lake (Fig. 3). 


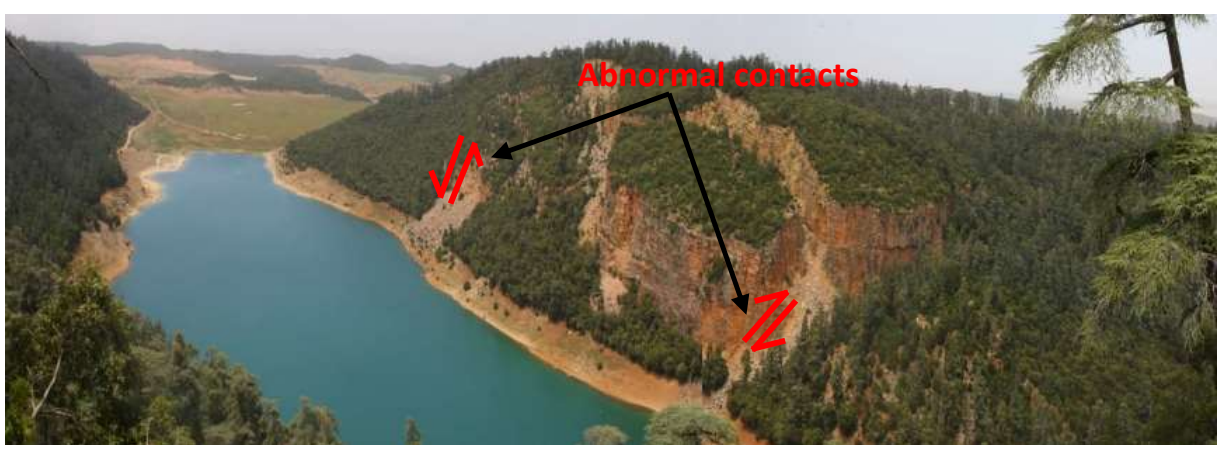

Fig. 3. Fractures in the carbonate rocks of AguelmamAzegzaLake.

\subsection{Karstification}

The karstification consists of the dissolution of rocks following an intense fracturing affecting the carbonate formations near the lake. These formations feed the lake by precipitation (snow and rain)(Fig.4).
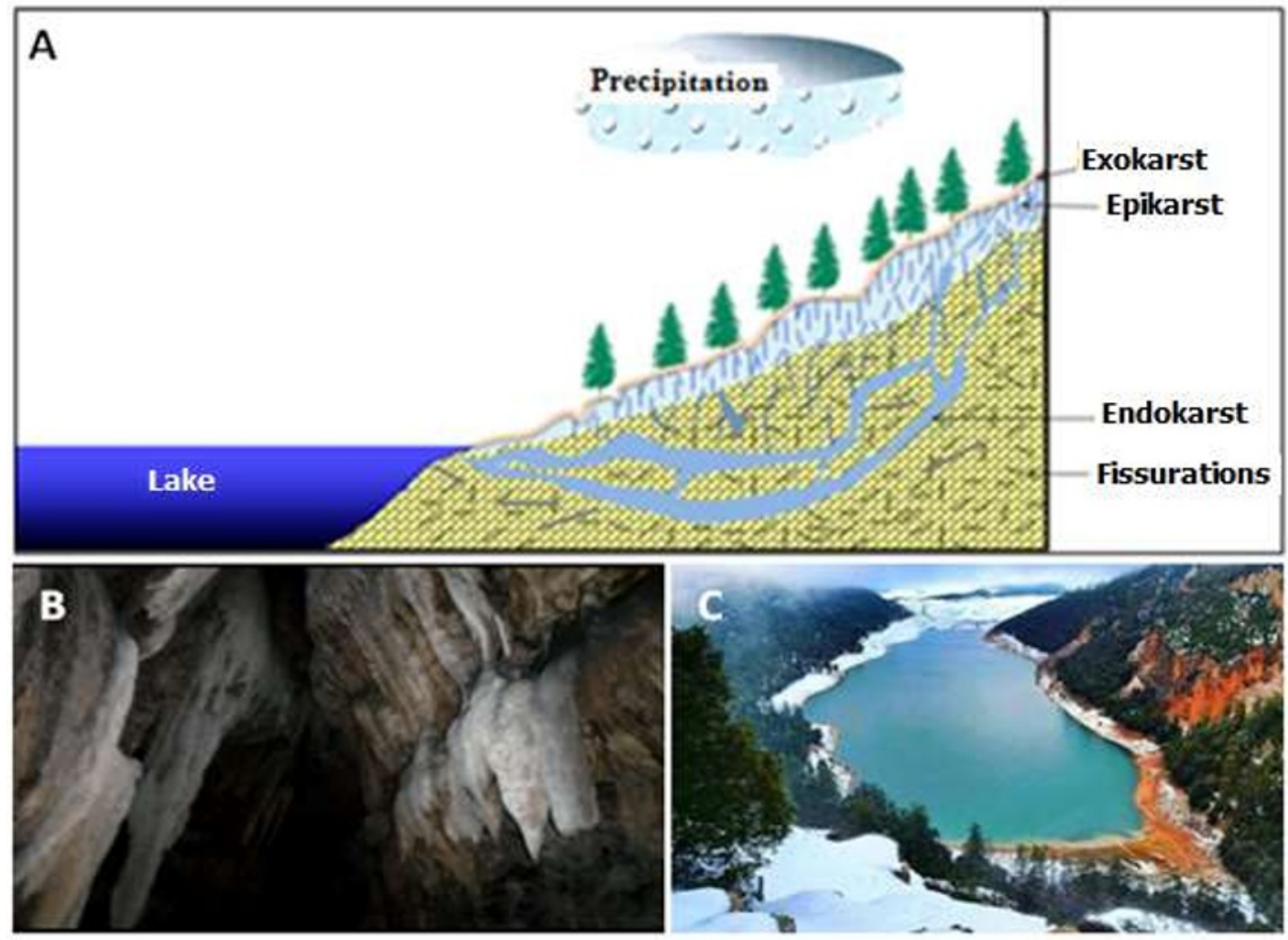

Fig. 4.A: Model of karstification of AguelmamAzegzalake, B: Photograph of karst in the vicinity of the lake, C: Photograph of the lake covered with snow in 2017.

In addition to the caves located to the north-east of the lake, such as Ifri Waman, the IfriWadou mountain on the eastern shore of the lake contains several caves, the largest of which is IfriWadou, named after the mountain. The latter has been studied by a team of Spanish speleologist (Subies and Benedito, 1993)(Fig.5). 

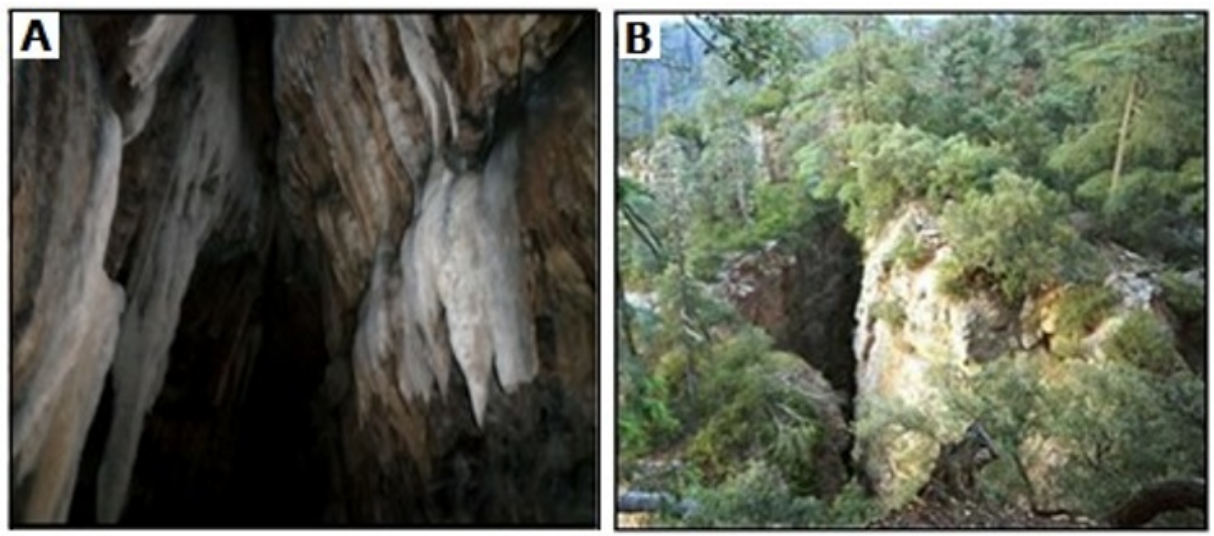

Fig. 5.Photos of caves A: Ifri Waman; B:IfriWadou

\subsection{Sedimentation of the lake}

The study of sedimentation at AguelmamAzegza shows that the rate of accumulation is around 4 to $5 \mathrm{~mm} /$ year. The sediments present a granoclassification where the distribution is decreasing from the edges towards the centre of the lake. At the edges, the proximity of the inflow and the strong hydrodynamic energy allow the deposition of coarser materials of millimetre size by excess load. These coarse particles are favoured by the inflow from the gullies, especially the one situated to the SE of the lake (Fig. 6). The winds also exert a significant erosive action on the banks. Towards the centre of the lake, the decrease in hydrodynamic energy favours fine micrometric sedimentation.
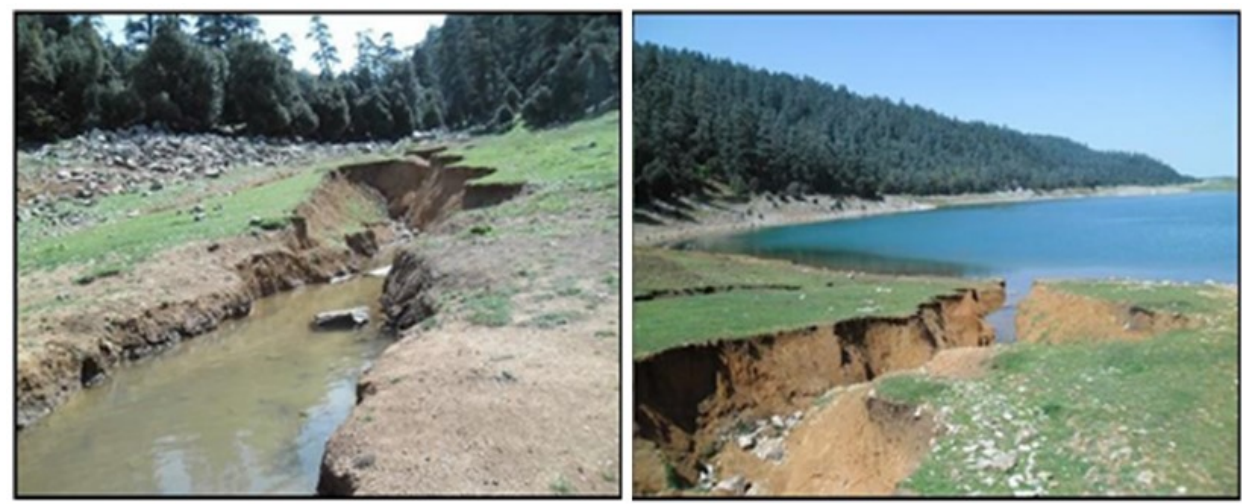

Fig. 6.Photograph of the gullies that feed the lake with sediments

\subsection{Main chemical elements of the lake water}

According to Table1, the lake waters of AguelmamAzegza are characterised by high concentrations of Calcium, Magnesium, Bicarbonates and Carbonates, with moderately low concentrations of chloridesand very low concentrations of Potassium, Sodium, Sulphates and Nitrates. These waters therefore have a calcic and magnesian bicarbonate hydrochemical facies. This facies reflects the lithological nature of the host rock, which consists of limestone and dolomite.

Table1.Concentration of the main chemical elements in lake waters

\begin{tabular}{|l|l|l|}
\hline Chimical elements & Concentration Average & Origin \\
\hline Carbonates & $11,02 \mathrm{mg} / \mathrm{l}$ & Alteration of carbonate rocks (limestone and dolomite) \\
\hline Bicarbonates & $281,26 \mathrm{mg} / \mathrm{l}$ & Alteration of carbonate rocks (limestone and dolomite) \\
\hline Sodium & $0,16 \mathrm{mg} / \mathrm{l}$ & Leaching of forest soil from the lake catchment \\
\hline Sulphates & $1,11 \mathrm{mg} / \mathrm{l}$ & Rainfall as a result of the presence of sulphur in the atmosphere \\
\hline Potassium & $1,02 \mathrm{mg} / \mathrm{l}$ & Leaching of forest soil from the lake catchment \\
\hline
\end{tabular}




\begin{tabular}{|l|l|l|}
\hline Chloride & $14,24 \mathrm{mg} / \mathrm{l}$ & Leaching of forest soil from the lake catchment \\
\hline Magnesium & $43,91 \mathrm{mg} / \mathrm{l}$ & Alteration of carbonate rocks (limestone and dolomite) \\
\hline Calcium & $64,12 \mathrm{mg} / \mathrm{l}$ & Alteration of carbonate rocks (limestone and dolomite) \\
\hline
\end{tabular}

\section{Climatic conditions}

\subsection{Precipitations}

The annual rainfall measured at AguelmamAzegza over the period 2000 to 2019 has recorded fluctuations that are particularly significant. This annual rainfall was very high in 2009-10 $(844 \mathrm{~mm}-680 \mathrm{~mm})$ and after a decrease in rainfall from 2011 onwards becomes lower in 2019-20 (13mm), these results are strongly correlated with those obtained from the study of lake level variation and therefore explain the trend of decreasing lake level in recent years(Fig.7).

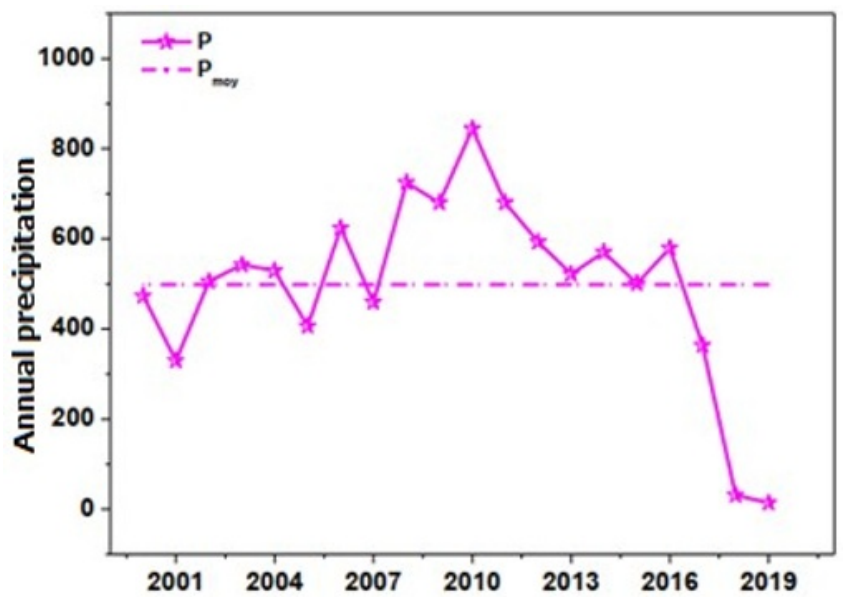

Fig. 7.Annual rainfall in AguelmamAzegza from 2000 to 2019

\subsection{Temperatures}

The temperature of the lake waters shows strong variations during the year, with a maximum value of $24.8^{\circ} \mathrm{C}$ recorded during the month of July, and a minimum value of $7.8^{\circ} \mathrm{C}$ recorded during the month of January, i.e. a difference of $12.64^{\circ} \mathrm{C}$. Indeed, lake waters are strongly dependent on external climatic conditions (Adallal et al., 2014). Underground water inputs $\left(\sim 12^{\circ} \mathrm{C}\right)$, which are in the form of sub-aquatic springs feeding the lake, also contribute to the decrease in lake water temperatures (Gayral and Panouse, 1954).

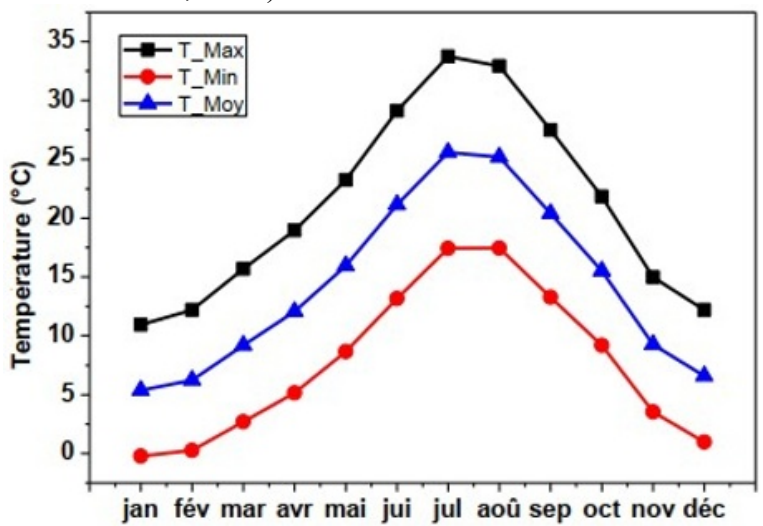

Fig. 8. Average monthly temperatures in AguelmamAzegza from 2000 to 2019

The average temperature values of the AguelmamAzegza station for the period 2000 to 2019 show that January is the coldest month $\left(5^{\circ} \mathrm{C}\right)$, while July and August are the warmest $\left(25^{\circ} \mathrm{C}\right)$ (Fig. 9). The average temperature is $13.48^{\circ} \mathrm{C}$, with annual average values between $12.46^{\circ} \mathrm{C}$ and $14.25^{\circ} \mathrm{C}$. 


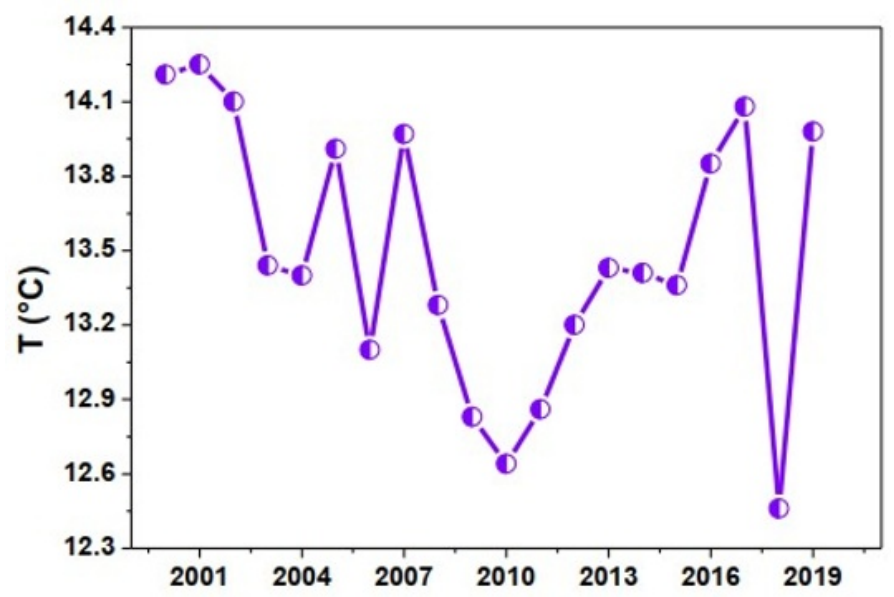

Fig. 9.Average annual temperatures in AguelmamAzegza from 2000-2019.

\section{The temporal evolution of the lake edge}

The understanding of the recent, past and future fluctuations of the AguelmamAzegza lake level, requires a good knowledge of the physiographic parameters of the lake (height $h$, surface $\mathrm{S}$ and volume $\mathrm{V}$ ), in order to describe the relationship between the changes of the lake volume and the inflow and outflow of the interconnected lake basin which will be defined as the AguelmamAzegza lake system in an accurate way. These parameters can be determined directly by placing oneself in the site, which requires adequate equipment and instruments, or by using the geographic information system (GIS). The latter alternative will be adopted in this study to achieve our objective. In this context, data from different sources of point observations and spatial information were collected and synthesised in order to clarify the water balance of the lake in a sensitive context of environmental changes.

In order to record the effect of climate changes on the water level of the lake, weproceeded to plot the lake's edges in two ways. The two ways adopted here are based on satellite images corresponding to the last years (from 2012 to 2020 ). The first one allows delimiting the lake borders using ArcGIS software, while the second one allows having them directly on Google Earth Pro.

According to the results, there is generally a narrowing of these curves representing the level of the lake as a function of time (Fig. 10), which reflects a decrease in the volume of water during these years. In contrast, the expansion of the curve corresponding to the year 2016 implies an increase in water volume during that year.

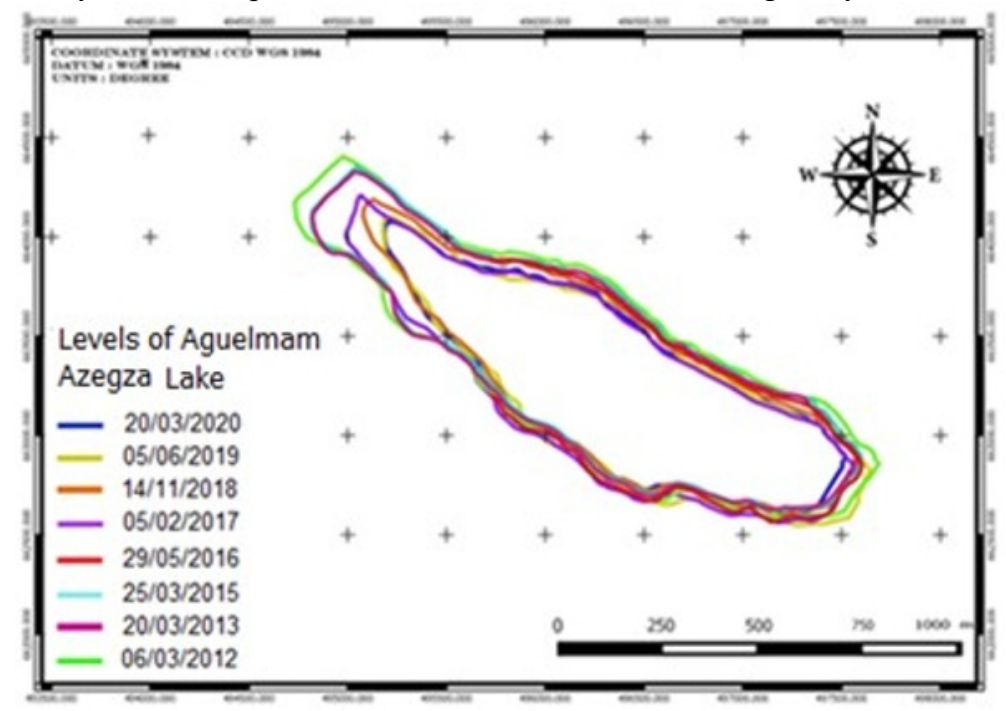

Fig. 10.Mapping the water adges of AguelmamAzegza lake based on satellite images(2012, 2013, 2015, 2016, 2017, 2018,2019 and 2020) 
These results are in good agreement with those found using the second method(Fig. 11). This trend of decreasing lake level has been demonstrated previously by Flower and Foster (1992) in earlier studies and that moreover the lake has varied in depth by $8 \mathrm{~m}$ during the 20th century.

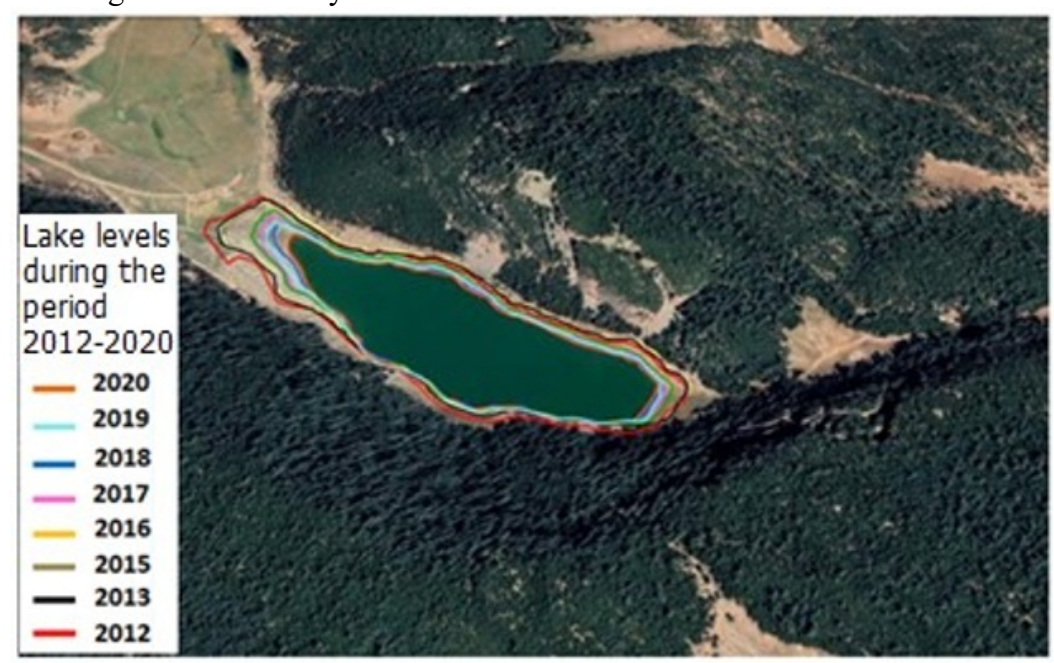

Fig. 11.Lake AguelmamAzegza levels between the years 2012 and 2020 on Google Earth Pro

Using data on the level of Lake AguelmamAzegza obtained from previous works (Gayral and Panouse, 1954; Flower and Foster, 1992; aerial photos from the mapping service, Rabat, 1964, 1973) and data acquired in the framework of this study, we were able to establish a chronicle of past lake levels based on satellite images and recent photographs(Tab.2). The data are plotted against the reference level established in 2012. All the data indicate that the lake has recorded decametric variations over the last few decades since the 1950s, with a maximum amplitude of fluctuations in its level of about $16 \mathrm{~m}$ (between the very high-level of $1456 \mathrm{~m}$ a.s.l. in 1965 and the very low-level of $1540 \mathrm{~m}$ a.s.1. in 2008 (Flower et Foster, 1992).

Tab.2.Historical fluctuations in the level of Lake AguelmamAzegza

\begin{tabular}{|c|c|c|c|c|}
\hline Date & $\begin{array}{l}\text { Lake level } \\
\text { (m a.s.l) }\end{array}$ & Perimeter(m) & $\begin{array}{l}\text { Surface } \\
\text { (Ha) }\end{array}$ & References \\
\hline 1949 & 1544 & $* * *$ & **** & \multirow{4}{*}{ Gayral et Panouse (1954) } \\
\hline 1952 & 1546.2 & *** & **** & \\
\hline 1953 & 1545.5 & $* * *$ & $* * *$ & \\
\hline 1954 & 1544.7 & $* * *$ & $* * *$ & \\
\hline 1965 & 1556 & $* * *$ & $* * *$ & $\begin{array}{l}\text { Aerial photo (1964), Mapping service, Rabat, } \\
\text { Rabat }\end{array}$ \\
\hline 1974 & 1552 & $* * *$ & $* * *$ & Aerial photo 1973, Mapping service, Rabat \\
\hline 1979 & 1549 & $* * *$ & $* * *$ & \multirow{3}{*}{ Flower et al. (1992) } \\
\hline 1982 & 1547 & $* * *$ & $* * *$ & \\
\hline 1985 & 1544 & $* * *$ & $* * *$ & \\
\hline 2008 & 1540 & $* * *$ & $* * *$ & Photo, https://mapsights.com \\
\hline 2012 & *** & $3869,04^{(\mathrm{b})}$ & 52,76 & \multirow{9}{*}{$\begin{array}{l}\text { Adallal }^{(\mathrm{a})}(2019) \\
{\text { current } \text { work }^{(\mathrm{b})}}\end{array}$} \\
\hline 2013 & $1546^{(\mathrm{a})}$ & $3692,63^{(b)}$ & 49,55 & \\
\hline 2014 & $1544^{(\mathrm{a})}$ & $* * *$ & $* * *$ & \\
\hline 2015 & $1543.5^{(\mathrm{a})}$ & $3355,28^{(\mathrm{b})}$ & $41,43^{(\mathrm{b})}$ & \\
\hline 2016 & $1543^{(\mathrm{a})}$ & $3531,02^{(b)}$ & $43,6^{(\mathrm{b})}$ & \\
\hline 2017 & $1542^{(\mathrm{a})}$ & $3261,06^{(\mathrm{b})}$ & $39,35^{(b)}$ & \\
\hline 2018 & $* * *$ & $3303^{(\mathrm{b})}$ & $38,2^{(\mathrm{b})}$ & \\
\hline 2019 & $* * *$ & $3151^{(b)}$ & $37,8^{(\mathrm{b})}$ & \\
\hline 2020 & $* * *$ & $2958,99^{(\mathrm{b})}$ & $34,22^{(b)}$ & \\
\hline
\end{tabular}

The fluctuation of the level of the lake can only be justified within the framework of the approach of Campy et al (2003) which links this variation of the level to two systems: the first is the catchment basin carrying the material and the second is the sedimentary basin which reacts as a receptor, hence the need for the lake's own water balance which expresses the equilibrium between the inflow and outflow of water. 


\section{Conclusion}

The AguelmamAzegza area is a favourable environment for the genesis of karstic formations through the dissolution of rocks following intense fracturing. The karstification allows, on the one hand, the penetration and storage of a very high proportion of meteoric water by infiltration.

Variations in precipitation and the temperature of the lake water over the last few decades have led to a reduction in the level of the lake. Indeed, the shores of the lake of AguelmamAzegza fluctuate according to the climatic conditions and particularly to the precipitations and the evapotranspiration and also to the dissolution of the carbonate geological formations.

Further studies are needed to assess the impact of socio-economic activities and land use combined with the effects of climate change on Azegza's water resources in order to better predict the evolution of the lake in the coming decades.

\section{References}

[1]. S. HinajeandL. AitBrahim. Les basins lacustres du Moyen Atlas (Maroc) : un exempled'activité tectonique polyphasée associée à des structures d'effondrement. Comun. Inst. Geol. E Minerio.89. pp. 283-294 (2002).

[2]. B. Lepoutre, J. Martin. Le causse moyen atlasique. Les cahiers de la recherche agronomique, $\mathrm{N}^{\circ} 24$ : Congrès de pédologie méditerranéenne 1966-Madrid. Excursion au Maroc. 2ème partie : description des régions traversées, chap. IV. pp. 207-226 (1967).

[3]. J. Martin. Le Moyen Atlas Central : Etude géomorphologique. Service Géologique du Maroc, Rabat. 482 pp (1981).

[4]. A. Bentayeb and C. Leclerc. Le causse Moyen atlasique. In: Ressources en Eau du Maroc.Service géologique du Maroc, Rabat, pp 37-84 (1977).

[5]. A. Benkaddour, A. Rhoujjati, M. Nour El Bait. Hydrologie et sédimentation actuelles au niveau des lacs Iffer et AguelmamAzegza (Moyen Atlas, Maroc). pp108-118 (2008).

[6]. J.V. Subies, V. Benedito. Exploración de la grangrietaIfriWadou. Grupo espeleológico "la senyera" c/. Monte carmelo, 4. Apdo. De Correos 216.Valencia. pp. 17-86 (1993).

[7]. R. Adallal, C. Vallet-Coulomb, A. Benkaddour, C. Sonzogni, F. Sylvestre. Water and isotope balances of AguelmamAzegza lake (Middle Atlas, Morocco). 41st IAH International Congress "Groundwater: Challenges and Strategies", Marrakech, Morocco (2014).

[8]. P. Gayral and J.B. Panouse. L’AguelmameAzegza : Recherches Physiques et Biologiques. Bulletin de la Société des Sciences naturelles et physiques du Maroc 36, 135-159 (1954).

[9]. R. Flower and I.D.L. Foster. Climatic implications of recent changes in lake level at Lac Azegza (Morocco). Bulletin de la Sociéte Géologique de France 163, 91-96 (1992).

[10]. R. Adallal, Variabilité environnementale des lacs du Moyen Atlas marocain : fonctionnement hydrogéochimique, hydrologique et réponse au changement climatique. Thèse,Université d'Aix-Marseille et Université Cadi Ayyad de Marrakech. 212p, (2019).

[11]. M. Campy, and J.J. Macaire. Géologie de la surface : Erosion, transfert et stockage dans les environnements continentaux. Compte-rendu p.279-280 (2003). 